\title{
Parenting adopted children and supporting adoptive parents: Messages from research
}

\author{
Anita Gibbs
}

Anita moved to Dunedin in 1999 from the UK where she had been a probation officer. Since then she has researched, taught and published extensively in areas as varying as home detention, social work research methods, community treatment orders and more recently intercountry adoption.

\section{Summary}

This article considers adoption from the perspective of parents, especially the strategies that they employ to enhance attachments and build positive parent-child relationships. The article draws particularly on recent New Zealand research regarding intercountry adoptive parenting, as well as overseas literature on good adoptive parenting practice generally in domestic and intercountry adoption. It also considers the research on methods of supporting parents who adopt and whether there are gaps in legislation, policy or practice in New Zealand that could be closed by borrowing from good examples in the literature, and, or current practice examples. The author is an adoptive parent of Russian-born children and is actively involved in adoptive parent support networks.

\section{Introduction}

There are two main pathways for people wishing to adopt in New Zealand. They can try to adopt a baby or infant domestically when a child has been placed for adoption by the birth parents (usually the birth mother) under the Adoption Act 1955, or they can attempt to adopt from several overseas countries under the Adoption (Intercountry) Act 2007, and parts of the Adoption Act 1955. The chances for most would-be parents of adoptive children within New Zealand are slim. Less than 45 babies were adopted domestically to non-relatives during 2009 (CYFS, personal communication, 2010). The intercountry opportunities are fairly limited as well, with less than 60 adoptions from Russia, China, Lithuania, India, the Philippines and Thailand in 2008 and 2009 (HCCH, 2010). Historically, most people in New Zealand have adopted from Russia, and since 1992 over 670 Russian-born children have been adopted by New Zealanders (ICANZ, 2010). Most people who wish to care for children not born to them do not go down the adoption route; instead, they are far more likely to foster and, or, care for a child long-term as a guardian under the Care of Children Act 2004. The guardianship route gives them the near equivalent of full parental rights. Currently in New Zealand there are just over 300 applicants waiting to adopt domestically and overseas (CFYS, personal communication, 2010).

The issues faced by adoptive parents are both similar to 'normal' parenting, and special, or, different. The similarities include: the need to develop attachments or nurturing relation- 
ships with their children, the need to provide shelter, food, warmth and communication i.e., to meet the basic needs of the child. Parents who have not adopted will, like adoptive parents, also face behavioural, health, social or other challenges as they parent their children. The special bit of adoptive parenting comes when adoptive parents are faced with one or more children who have been abused or severely neglected; who have spent time in an institution; who have suffered loss; who also may have a range of developmental delays, and significant social, relational, health and learning needs. In this case, parents are likely to need a lot of extra help in the form of service supports, assessments and counselling. They may have to be especially tenacious over and above an average parent's tenacity to get the services they need to help them care for their adoptive children.

We now turn to review a variety of research studies undertaken in New Zealand and internationally to explore good practice in adoptive parenting and in supporting adoptive parents, and this includes reference to both intercountry adoption and domestic adoption.

\section{Studies in New Zealand}

A study of New Zealand parents' views of intercountry adoptive parenting was undertaken in 2007 (Johnstone and Gibbs, 2010; Johnstone, 2007). This study involved interviews and focus groups with 15 parents (six fathers and nine mothers) who had between them adopted 19 Russian-born children between 1996 and 2004. The aim of the study was to explore how parents developed attachment and parenting relationships with their children. Parents highlighted a number of strategies they used, as well as personal qualities they felt that they and their children possessed, which helped with attachments. Preparing to be a parent was viewed as an important first step to ensuring they would help their adoptive children. Many of the parents went on courses, read books, consulted the internet, spent time with other adoptive parents and reflected on their own parenting. As these parents were intercountry adoptive parents they also spent time in learning about the effects of institutionalisation, neglect and development delays or health issues likely to affect their child.

Once parents had met and, or, adopted their children the key thing that assisted good parent-child relations was time: lots of it, whether in play, or cuddling, or communication. Most of the parents took time off work, especially the women, or even gave up their jobs. The dads also spent their non-work time with the children wherever possible. Parents could not over emphasise the time needed to develop bonds with their children: as one dad put it 'hugs, kisses and holding hands ... lots and lots of times but you can't do it too many times with these kids ... they were craving it' (Johnstone \& Gibbs, 2010, p. 18). Another strategy that parents employed was to limit the environment so that their children would not become over stimulated. Hence, they kept visitors and outings down to a minimum in the first few weeks or months; they discouraged others from holding or feeding their children so as to reduce confusion about who mummy or daddy was; and they often delayed starts to childcare or primary education until they felt their children were ready.

One of the important strategies used to enhance their parenting capacity was to access and use group and family-based supports. Where parents were married they 'team-tagged' with their partners and relied heavily on one another to share the stresses of parenting; they also encouraged extended family to get involved or had honorary family members. They accessed playgroups, churches and a whole range of health and social services when they 
could - this was much easier for people living in cities than in rural areas. Importantly, adoptive parents sought out other intercountry adoptive parents and through networks like ICANZ (Intercountry Adoption New Zealand) they regularly met for support.

Parents felt that they and their children had particular strengths and qualities that had seen them through some tough times in their adoption journey. They noted that ability to cope with great amounts of stress was an asset for parents and children. Both parties needed patience and tolerance to manage rapid change over short periods of time. Parents' abilities to commit and be tenacious were viewed as necessary and helpful to building attachments. A determined positive parenting approach was revealed by parents as they talked of sticking with their children through challenging times, giving them the messages that they as parents were always there for the children, and signalling to the children that they were a priority. The parents' approach was child-centred. One mother spoke of her son in this way: 'commitment and loyalty to stick with even when times are tough. You took this boy on, you grind away and eventually the sun starts to shine' (Johnstone \& Gibbs, 2010, p. 25).

This study (Johnstone \& Gibbs, 2010; Johnstone, 2007) highlighted a number of areas where a better understanding of adoption and the challenges of adoptive parenting would have led to better attachment relationships. Feelings of being scrutinised by others; professionals, especially social workers, having a problem-based view of adoption; adopting older children, and not limiting the environment, were all deemed areas that influenced how parents tried to build good parent-child relations. It was also clear that levels of support for newly adoptive families varied enormously and, while adoptive families were good at supporting other adoptive families, professional help was a hit-and-miss affair, and relied upon proactive parents pushing to get help.

No other studies on parenting and intercountry adoption have specifically been undertaken in New Zealand, but there are two studies on general intercountry adoption processes and the wellbeing of children (De Jong, 2001; Wilson, 2001). Wilson (2001) explored the role of women, in particular, in the decision to adopt from overseas, and the experiences of 10 couples about their overall ICA experiences. The author concluded that women are often the drivers to adopt, and that they ultimately become the main day-to-day caregivers of adopted children. De Jong (2001) explored the wellbeing of 62 Russian-born adopted and 54 Romanian-born adopted children, and while most were fairing well parents reported greater behavioural problems than non-adopted comparisons. Of relevance to parenting was that parents reported little post-adoption support and understanding by agency professionals of adoption-related problems (De Jong, 2001). There have also been some personal/ autobiographical accounts by parents of their trials and tragedies regarding parenting children adopted from overseas (Graham, 2006; Stace, 1997).

One important aspect of developing positive relationships between adoptive parents and children may be the attention paid to culture and identity where adoption has been intercountry or transracial. Studies by Scherman and Harre in New Zealand (2004; 2008) on parents' views of culture and identity, and overseas (Carstens and Juliá, 2000; Heimsoth and Laser, 2008) on cultural and ethnoracial awareness, show how parents make great efforts to help children understand and benefit from knowledge about their ethnic and cultural background. Where parents make practical efforts to help children appreciate their cultural and ethnic heritage then children tend to be more positive in their cultural and ethnic identities. 


\section{International studies of good adoptive parenting}

There have been a large number of international studies exploring adoptive parenting and it is not within the scope of the piece to entirely review these. Nevertheless, it is important to highlight the main research findings. Many of the studies confirm the results from the Johnstone (2007) study. Hence, good adoptive parents should be able to: understand and respond to a child's needs; show respect and love; touch and hold appropriately; be consistent in providing structure and boundaries for a child; spend quality time with a child in communication and play; ask for help when help is needed; and make good use of supports - familial, health, social services or support groups (Flynn, Welch and Paget, 2004; McGuiness, Ryan, and Robinson, 2005; Rushton, 2003; Sturgess and Selwyn, 2007). Parents will need to have good communication skills and a positive attitude, ability to access resources, good problem-solving skills including flexibility, and realistic expectations and high levels of commitment towards children who have often experienced poor attachments (Brodzinsky and Pinderhughes, 2002; Evan B. Donaldson Adoption Institute, 2004; McRoy, Courtney, Chanmugam, Madden, Ayers-Lopez, 2009).

Research findings from studies of adoptive parenting show that a number of factors are more likely to lead to disruption and, or, poor parent-child relations. These factors include older age at adoption, time in care or institutions, poor attachment patterns, and a high level of behavioural challenges (Rushton, Mayes, Dance, Quinton, 2003). More recently, poor matching by social work professionals of children with high needs to new families has been highlighted as an issue contributing to adoptive placement breakdown (Dance, Ouwejan, Beecham, Farmer, 2010). For some of these factors very little can be done to 'undo the past'; but for others help can be provided 'to promote the quality of the relationship between children and their new parents' (Rushton et al., 2003, p. 389). Indeed, there is an increasing literature showing the benefits of support to keeping adoptions intact and enabling positive adoptive relationships (Evan B. Donaldson Adoption Institute, 2004; Sturgess and Selwyn, 2007). With regard to matching issues, recent research suggests that improvements need to be made in the areas of provision of quality and honest information from professionals about children to would-be adoptive parents, as well as greater efforts in finding the right family for children with high or special needs, and enhanced post-adoption support for those families (Dance et al., 2010).

In domestic and intercountry adoptions the need for parents to consider openness and contact may also be a factor affecting relationships. This is a large area of practice and research and a few short lines cannot do it justice. The evidence is conflicting, with some research suggesting contact with birth parents is good but other research indicating negative outcomes from contact (Curtis \& Pearson, 2010; Neil, 2009; Parker, 1999). There is new research underway in New Zealand to ascertain views of adoptees and their adoptive parents about the level and benefits of post-adoption contact in intercountry adoptive situations (ICANZ, 2010).

\section{Parenting support}

Adoptive parents do not come into life with a gene for adoptive parenthood, and there are many times in the life of an adoptive family when love and common sense are just not enough. Adoptive parents need information and guidance to help them cope with the many challenges of adoptive family life (Palacios \& Sanchéz-Sandoval, 2005, p. 142). 
Also,

Adoptive families are for the most part healthy and well motivated and want a partnership with professionals to help them deal more effectively with special parenting difficulties and challenges (Rushton, 2003, p. 43).

These two quotes illustrate well the fact that most adoptive parents do a great job and manage to develop good attachments by just doing what they think is best, but occasionally they could do with a bit of help from skilled others (aka, professionals perhaps but not always so, could be grandparents). Support for parents who adopt can come in many forms, and sources of support might be formal (e.g. social services), semi-formal (e.g self-help or community groups) and informal (friends and grandparents for example) (Quinton, 2004). The kinds of support might include practical, financial, emotional or moral, giving advice, and offering resources or services (Parker, 1999). Support offered by professionals and other groups inevitably varies; support requested will vary too.

In New Zealand, a great deal of the support for adoptive parents comes from immediate friends and family and adoption support groups like ICANZ (http: / / www.icanz.gen.nz) and Open Adoption Network (OPAN) (www.opan.org.nz). Little support is organised by professional social services, although individual social workers often offer a quality service when they can. Adoptive parents in New Zealand need to be proactive to gain specialist health, psychological and counselling support with regard to the needs of their adoptive children and their own needs as adoptive parents. The legislative, policy and practice approaches in New Zealand focus on pre-adoption and help for adoptees regarding contact with birth parents. In the UK, however, there is specific legislation (The Adoption Support Services Regulations 2005) to allow for post-adoption assessment and support. Most local authorities in the UK have specialist post-adoption support services and workers. There are extensive groups and individual post-adoption supports in place led by social services and social workers. Some of these post-adoption initiatives have undergone evaluation and I now refer to two recent evaluations.

Adoption UK is an adoptive parent-based organisation committed to advocacy and support of adoptive families (www.adoptionuk.org) and runs a group-based post-adoption support programme called 'It's a Piece of Cake?' . The programme offers 30 hours of group-based activity over six modules aimed at enhancing adoptive parenting skills and approaches. The programme is run by trainers who themselves are adoptive parents. To attend a programme parents must have had a child with them for 12 months or more. The 'Cake' programme as it is known was evaluated recently (Selwyn, del Tufo and Frazer, 2009), and parents reported more confidence in their abilities to parent their children, and an increased skill repertoire to manage challenging behaviours. Parents also found the groups offered mutual support from other parents experiencing similar issues (Selwyn, del Tufo and Frazer, 2009). In New Zealand adoptive parents can get access to parent-based group interventions such as the groups provided by Parents Inc. (http: / / www.parentsinc.org.nz/cms/), or health-based psychologist services. However, these groups rarely touch on adoptive parenting issues, and rarely do course trainers have experience of adoption.

In another UK study, Rushton and colleagues (Rushton and Monck, 2009) also evaluated specific post-adoption support initiatives to assist adoptive parent-child relations. It looked at two parent support interventions that were provided on a one-to-one basis to 
parents with adoptive children exhibiting behavioural problems (Rushton and Monck, 2009). One intervention was a cognitive behavioural parenting advice programme, and one was a tailor-made adoptive parent education programme. Two groups of parents receiving these interventions were compared with a control group who received the routine 'service as usual' from social services. Each of the interventions involved 10 weekly sessions at home, and were delivered by family social workers. Adopters were interviewed and questionnaires were administered before and after the interventions. Parent satisfaction with both interventions was high, compared to the control group, and adopters said they valued the regular home-based visits which took account of their specific family needs. The study authors concluded that parents gained increased satisfaction and confidence in their parenting abilities as a consequence of additional focused input from well qualified professionals which was tailor-made to suit parents' needs (Rushton and Monck, 2009).

In the US and Europe there are also excellent examples of post-adoption programmes and support (Barth \& Miller, 2000; Barth, Crea, Karen Thorburn \& Quinton, 2005; Brodzinsky, 2008; McRoy et al., 2009; Juffer, Bakermans-Kranenburg \& van Ijzendoorn, 2007). Brodzinsky (2008) in particular notes that in order to support families a 'comprehensive and lifelong support system' must be in place and that professionals need to promote a balanced view of adoption. Also, that more evidence-based adoption support programmes must be developed and implemented. Juffer and colleagues in Holland (Juffer et al., 2007) have developed an evidence-based parenting programme, now used widely in many settings. In the Dutch programmes professionals and others use dvd/video playback and feedback to assist parents with their communication skills with their adopted children. Good parenting communication and parental sensitivity are deemed critical skills and according to Juffer et al. (2007) help for parents should be geared to enhancing these skills or traits.

\section{Practice/policy implications}

There are areas where New Zealand can do better in the legal, policy and practice systems. In this section I wish to make a few suggestions based on the research previously outlined, and my own and other adoptive parents' experiences of these systems.

The Adoption Act 1955 needs to be updated to reflect the changing world of adoptive practices, especially with regard to openness, and the needs of families with older children who are likely to need more post-adoption support than families who adopt very young babies. The UK Adoption Support Services Regulations 2005 which impose a duty on social services to offer post-adoption assessment and assistance to adoptive families, is one such example that New Zealand could add to a new Adoption and Support Services Act. The UK regulations offer support by specialist adoption support workers (mostly qualified social workers) in the following ways: assessment, counselling, advice and information; financial support; services to enable groups of adoptive families to meet; contact services and mediation to assist with organising contact with birth families, therapeutic needs' services, and assistance to build the relationship between adoptive parents and adopted children. This support not only covers adoptive families but also wider networks associated with adoption e.g natural siblings of adopted children, birth parents, any child of adoptive parents not just the adopted ones, former guardians of the adopted child, people related to the adoptive child and people wishing to adopt. It is fairly comprehensive. 
Most parents of adoptive children would value and need additional help at some point in their adoptive-parenting journey. Many studies have highlighted the need for parents to have assistance at all stages of the adoption journey, e.g. during pre-adoption preparation and assessment to adopt, going through placements and procedures, and post adoption (Palacios \& Sanchéz-Sandoval, 2005; Sturgess \& Selwyn, 2007). Children's needs and issues are more marked at the early stages of adoption but challenges often exist for many years and it is therefore vital that parents in New Zealand are offered a greater range of support services than they currently receive. Just because they are few in number does not make their unmet needs any less significant. There are excellent examples of tailor-made adoptive-parent interventions from overseas and there is no reason why agencies such as Child, Youth and Family should not look to use these here.

At the outset of an adoption, whether domestic or intercountry, the first 6-12 months should be viewed as a time crisis and opportunity, and thereby social work services should be regularly available to help families maximise their relationship building (Johnstone \& Gibbs, 2010). With a newborn baby the first 6-12 months are critical, so with a newly formed adoptive relationship the first 6-12 months set the pattern for the parent-child relationships thereafter. The first 6-12 months, particularly where a child is older, is a highly stressed time and everyone is emotionally, and in some cases physically, vulnerable, even more so where language is a barrier. A crisis-intervention and strengths-based approach will enable quick responses and help from professionals but at the same time will allow a positive viewing of the adoptive parent-child relationship as a whole. Parents in the Johnstone (2007) study commented that they did not like the way social workers came across as viewing adoption as a problematic issue. Other adoptive parents have commented they do not like feeling under scrutiny by professionals or the wider public, and this leads them to be less likely to ask for help when they experience parenting challenges, for fear of being viewed as an inadequate parent (Parker, 1999). Hence, we need to create a professional culture of support and acceptance for adoptive families. The only way this can happen is to give professionals more training, resources and time to be available to offer post-adoption support. Two excellent sources of materials to help social work professionals are the British Association for Adoption and Fostering (BAAF) and the Evan B. Donaldson Institute websites (http: / / www.baaf.org.uk/index.shtml, http: / / www.adoptioninstitute.org/index.php), from which research reports, practice support guidance and information about adoption courses, policy, and law can often be downloaded for free, or at a low cost.

Much of the help offered to parents post adoption will need to focus on both attachmentpromoting interventions as well as interventions designed to reduce behavioural challenges (Rushton et al., 2003). Specific needs assessment could be undertaken during the first six months and then after 18 months or later depending on whether services have been accessed and found to be useful. Adoptive children's needs and relationships change over time and it is important to bear in mind that at different times in a child's life they may need different kinds of intervention, that is why a long-term view of building positive parent-child relations is a valuable perspective to hold (Rushton, 2003; Sturgess and Selwyn, 2007).

Providing ongoing postadoption support for parents that is not just triggered by stressed parents asking for help when they are struggling, is also an approach which will help parents feel confident that social work professionals are working in partnership with them, aimed at the same outcomes - resilient, confident, content children who like themselves and their 
families! The only way to do this is to make sure parents feel affirmed in their parenting, and to help them trust social workers. Social workers could offer assistance to parents as a matter of course in accessing services other than social services, in contacting other adoptive parents/families for support, and in giving positive feedback when they think parents are doing a good job. This is not patronising. A lot of parents doubt their abilities and when they have challenging behaviours from their adopted children the doubts may increase. A positive communication from a social worker at a delicate time may well affirm to parents

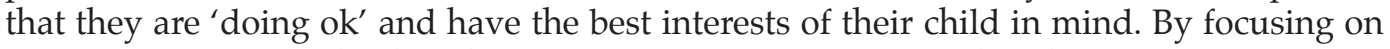
resiliency and strengths the whole family is likely to benefit rather than just one or two of the family members.

\section{Conclusion}

Adoptive parents are a tenacious group of adults who attempt to parent children who have a likely history of adverse experiences. Most studies show positive parenting and positive parent-child relationships, but to enable progress in parenting sometimes extra support is required from friends, family and professional services. Adoptive families need to be assessed at different times in their adoptive journey, and specialist social work or other postadoption services can make an important difference to the quality of the relationships in the adoptive family. We should not underestimate the importance of post-adoption services for the long-term welfare of adoptive families.

\section{References}

The Adoption Support Services Regulations 2005. (2005). Statutory Instrument 2005 No. 691. London, UK: The Stationary Office.

Barth, R., \& Miller, J. (2000). Building effective post-adoption services: What is the empirical foundation? Family Relations, 49(4), 447-455.

Barth, R., Crea, T., Karen, J., Thoburn, J., \& Quinton, D. (2005) Beyond attachment theory and therapy: Towards sensitive and evidence-based interventions with foster and adoptive families in distress. Child and Family Social Work, 10(4), 257-268.

Brodzinsky, D.M., \& Pinderhughes, E.E. (2002). Parenting and child development in adoptive families. In M. H. Borstein (Ed.) Handbook of parenting: Vol. 1. Children and parenting, pp. 279-311. Mahwah, NJ: Lawrence Erlbaum Associates.

Brodzinsky, D.M (2008) Adoptive parent preparation project phase 1. New York: Evan B. Donaldson Adoption Institute.

Curtis, R., \& Pearson, F. (2010). Contact with birth parents. Journal of Social Work OnlineFirst, June 30, 2010. DOI: $10.1177 / 1468017310369273$. pp.1-21.

Carstens, C., \& Juliá, M. (2000). Ethnoracial awareness in intercountry adoption: US experiences. International Social Work, 43(1), 61-73.

Dance C., Ouwejan D., Beecham J., \& Farmer E. (2010) Adoption agency linking and matching: A survey of adoption agency practice in England and Wales. London: BAAF.

De Jong, D.K. (2001). The well-being of Russian and Romanian intercountry adoptees in New Zealand. MSW thesis. New Zealand: University of Massey.

Evan B. Donaldson Adoption Institute. (2004). What's working for children: A policy study of adoption stability and termination. New York: Evan B. Donaldson Adoption Institute.

Flynn, C., Welch, W., \& Paget, K. (2004). Field-initiated research on successful adolescent adoptions: Final report 2004. Retrieved October 2009 http: / / www.sc.edu / ccfs / research / fullfinalreport.pdf.

Graham, J. (2006). How many planes to get me? Auckland: Cape Catley.

Heimsoth, D., \& Laser, J. A. (2008). Transracial adoption: Expatriate parents living in China with their adopted Chinese children. International Social Work, 51(5), 651-668.

HCCH. (2010). Annual adoption statistics for receiving states. Country: New Zealand. Retrieved September $2010 \mathrm{http}$ / / www.hcch.net/index_en.php?act=publications.details\&pid=5068\&dtid=32

ICANZ Intercountry Adoption New Zealand. (2010). ICANZ. Retrieved March 2010 http: / / www.icanz.gen.nz/

Johnstone, J. (2007). Factors influencing the attachment journey of adoptive parents with a Russian child. Master of Arts thesis, Dunedin: University of Otago. 
Johnstone, J. and Gibbs, A. (2010). 'Love them to bits; spend time with them; have fun with them': New Zealand parents' views of building attachments with their newly adopted Russian children. Journal of Social Work. In press.

Juffer, F., Bakermans-Kranenburg, M., \& van Ijzendoorn, M. (2007). (Eds). Promoting positive parenting. New York: Taylor and Francis.

McGuiness, T. M., Ryan, R., \& Robinson, C. B. (2005). Protective influences of families for children adopted from the former Soviet Union. Journal of Nursing Scholarship, 7(3), 216-221.

McRoy, R. G., Courtney, J. L., Chanmugam, A., Madden, E., \& Ayers-Lopez, S. (2009). Children from care CAN be adopted. In G. M. Wrobel and E. Neil (Eds), International advances in adoption research for practice pp. 97-118. Chichester: Wiley-Blackwell.

Neil, E. (2009). Post-adoption contact and openness in adoptive parents' minds: Consequences for children's development. British Journal of Social Work, 39(1), 5-23.

Quinton, D. (2004). Supporting parents: Messages from research. London: Jessica Kingsley.

Palacios, J., \& Sánchez-Sandoval, Y. (2005). Beyond adopted/nonadopted comparisons. In D. M. Brodzinsky and J. Palacios, (Eds). Psychological issues in adoption (pp. 117-143). Westport: Greenwood Publishing Group.

Parker, R. (1999). Adoption now: Messages from research. London: Wiley.

Rushton, A. (2003). Support for adoptive families: A review of current evidence on problems, needs and effectiveness. Adoption and Fostering, 27(3), 41-50.

Rushton, A., \& Monck, E. (2009). Enhancing adoptive parenting. London: BAAF.

Rushton, A., Mayes, D., Dance, C., \& Quinton, D. (2003). Parenting late-placed children: The development of new relationships and the challenge of behavioural problems. Clinical Child Psychology and Psychiatry, 8(3), 389-400.

Scherman, R., \& Harre, N. (2004). Intercountry adoption of Eastern European children in New Zealand. Adoption and Fostering, 28(3), 62- 72.

Scherman, R., \& Harre, N. (2008). The ethnic identification of same-race children in intercountry adoption. Adoption Quarterly, 11(1), 45-65.

Selwyn, J., del Tufo, S., \& Frazer, L. (2009). 'It's a piece of cake?' An evaluation of an adopter training programme. Adoption \& Fostering, 33(1), 30-43.

Stace, R. (Ed.) (1997). Love has no borders - true stories of the tragedy and triumph behind intercountry adoption. Auckland, NZ: Howling at the Moon Publications.

Sturgess, W., \& Selwyn, J. (2007). Supporting the placement of children adopted out of care. Clinical Child Psychology and Psychiatry, 12(1), 13-28.

Wilson, C. (2001). The process of intercountry adoption: The role of women within the couples involved. MSW thesis. New Zealand: University of Massey. 